\title{
Adapting Desires in Aphra Behn's The History of the Nun
}

\author{
Aleksondra Hultquist \\ ARC Centre for Excellence in the History of Emotion, 1100-1800
}

The plot of Aphra Behn's The History of the Nun; or the Fair Vow-Breaker (1689) is sensational-a former nun named Isabella unintentionally commits bigamy by marrying a second husband while the first is still alive. When she discovers her mistake, she murders both husbands by smothering the first, sewing the sack containing the corpse of the dead husband to the living husband's clothing, and encouraging the live husband to throw the corpse into a river, where he drowns. The bigamous wife freely confesses to the murders of "two husbands (both beloved) in one night" ${ }^{\prime 1}$ and is beheaded, to the dismay of the town. The plotline makes it easy to understand why this story was so fascinating to writers and audiences and thus so frequently rewritten in the long eighteenth century. Between 1694 and 1757, there were at least five adaptations. ${ }^{2}$ Modern critics have focused on Thomas Southerne's play, The Fatal Marriage: or, the Innocent Adultery (1694), David Garrick's 1757 revision of Southerne's play into the tragedy Isabella: or, the Fatal Marriage, and Jane Barker's short fictional excerpt, "Philinda's Story out of the Book" in The Lining of the Patch-Work Screen (1726). ${ }^{3}$ My research has unearthed two previously unknown texts, both moral fables in periodicals, the first in The Universal Spectator, under the heading "Sure, of all Ills, Domestic are the Worst!" (ca. 1728) ${ }^{4}$ and the second in The Gentleman's Magazine, which condensed the Universal Spectator version in 1731 as "Matrimonial Murders." ${ }^{5}$ Several critics have commented at length on the heroine's ability in Behn's novella to inspire both horror and sympathy from readers (sometimes simultaneously). ${ }^{6}$ But despite these analyses, the possibilities of what the adaptations can reveal about the original text has not yet been fully explored.

This essay uses adaptation theory in order to demonstrate that the problem of female sexual desire is always at stake in the adaptations-the way the protagonist struggles with desire, and the social implications of expressing desire-and each version's method of depicting the heavy burdens associated with that desire. In all of the versions, the heroines' desires and responses are 
extreme. What changes among the adaptations are the expressions of that intensity and the critique of the way in which patriarchal ideology (which manifests in the dictates of parents, monastic discipline, and marriages) produces such intensity. Additionally, adaptation theory demonstrates that none of the interpretations can completely overwrite Behn's text. For all the simplifications of character each successive adaptation exhibits, Behn's predominant critique of the ineffectiveness of patriarchal structures to deal with intense female desire is always reiterated through the "adaptive event," a literary moment invented by the revisions that does not exist in the source text. Through the lens of adaptation theory, it becomes clear that the latter versions simplify the protagonist's character in order to explain her motivations.

Jacqueline Pearson's significant article, "The History of The History of the Nun," first analyzed the Southerne, Barker, and Garrick versions, but Behn scholarship has changed since this 1993 publication. For instance, women writers are no longer "usefully" divided into Astreas and Orindas, ${ }^{7}$ and we accept easily the "complexity of Behn's symbolism and narrative methods," as (thanks to scholarship like Pearson's) Behn's significance to Restoration literature is now a given. For Pearson, whose reading is heavily informed by the concerns of feminist criticism, revisions of The History of the Nun simplify or splinter the heroine, demonstrating subsequent authors' inability to reproduce Behn's complex Isabella due to gendered re-readings of the text. Male and female anxieties of influence are different for Pearson's reading and are clearly demonstrated in her analysis that "whereas Southerne's Isabella is a saint and Barker's is a monster, Behn's is Everywoman." ${ }^{\prime \prime}$ Re-evaluating the current scholarship and including the periodical versions in the analysis belies the bifurcated existence of the adaptations as gendered readings. This is not to undermine Pearson's work; much of the scholarship on The History of the Nun, my own reading included, is indebted to Pearson's initial analysis. Her article uncovers connections to other texts that might have been more obvious to eighteenth-century readers and theatergoers, and her appraisal of sewing in the adaptations has been significant in subsequent readings of the text. ${ }^{10}$ But twenty years later it is no longer necessary (thank goodness!) to place Behn's work in a specifically gendered conversation.

Just as a feminist reading only gets one so far in untangling the adaptations, so a study of genre tends to fall short. While it can be useful to determine how the protagonist changes due to the constraints of the genre, such an exercise only goes so far in analyzing the significance of those changes. While, for instance, Garrick's Isabella is tragic because she is in a tragedy, such a close reading tends to belie more rigorous analysis and can only partially account for the changes in her character. Adaptation theory is necessary to make clearer sense of the significance of the changes that genre demands, as well as to understand what the authors maintain or add in the course of generic changes, and why they might do so. Adaptation theory aids in understanding this particular 
Aphra Behn afterlife and demonstrates how neither the generic changes nor the gender of the author can erase her core critique that patriarchal structures are detrimental to desiring women. Though the protagonists diverge from Behn's original, the fact remains that parents, monasteries, and marriages cause her problems.

While it is certainly possible to read any adaptation as a stand-alone work, scholars have begun to consider adaptations as adaptations, as conversations between texts within their specific historical and generic frameworks. ${ }^{11}$ I use three principles of adaptation theory to structure my readings of the later versions of Behn's The History of the Nun. First, every adaptation is an individual act of thinking and interpretation; in other words, the adaptations are not "lesser" than the source text simply because they are derivative. ${ }^{12}$ Each version of the plot of the History of the Nun and the character of Isabella is a rereading, an authorial reinterpretation of a complex and contradictory character who perpetrates violent and seemingly incomprehensible acts for complicated motives. All of the versions have the potential to send us back to Behn's original character with new questions and new insights.

Second, I focus on what later authors add to the text, rather than what they omit. Imelda Whelehan argues that it is more fruitful to examine adaptations in terms of excess rather than lack, in particular, the ways in which additions often introduce an adaptive "event" "that simply does not and could not appear in the [originary] text" which helps to explain or visualize a moment which is unclear or absent in the original. ${ }^{13}$ All iterations invent "adaptive events" to try to explain Isabella's murderous response to her first husband's return. In effect, the adaptations do their best to provide or supplement the "missing" psychological motive for these murders. In each adaptive event, the adaptations tend to essentialize the protagonist by making her a model of virtue or a monstrous manipulator.

Third, I consider these adaptive events in terms of what they reveal about Behn's text by using Linda Hutcheon's notion of "overwriting," of seeing the adapted text not only for what it is, but also for the "intrinsic memory" that an adaptation carries with it in new iterations. As Hutcheon suggests, "adaptation is a form of intertextuality: we experience adaptations (as adaptations) as palimpsests through our memory of other works that resonate through repetition with variation." ${ }^{14}$ In this respect, Behn's patriarchal critique-of irresponsible parents, greedy monasteries, inappropriate marriages, and stifling masculinist ideologies-resonates through all of the adaptations, although in different forms and with different emphases. Key elements remain constant in all the adaptations, particularly the bigamous marriage and the climactic death scenes. The variations in each adaptation, and the repetition of patriarchal critique, become crucial in gauging a seven-decade view of Isabella, and centrally for my study, allow us to reread the original text and its emphasis on female desire. No matter how many times adapters overwrite The History of the Nun, 
none of them can completely write out Behn's critique of patrilineal ideology as a source of conflicting demands on and extreme responses by the heroine.

\section{BEHN'S ISABELLA: COMPETING DESIRES}

Behn's The History of the Nun, like amatory fiction more generally, explores the competing discourses that define eighteenth-century feminine desire to suggest that pious, exceptionally moral women also can be confused, sexually desiring women. ${ }^{15}$ The adaptations try to resolve the paradoxes of these competing discourses by making the colorful main character more monochromatic. Behn creates a heroine who embodies the conflicting versions of the perfect woman: she is both a pious nun who wants heavenly approval and a sexually desiring subject who leaves the monastery to marry. Significantly, Behn is careful to suggest that Isabella's desires are not the problem. Behn creates a situation in which Isabella is "right" to take nun's vows, and to love both Henault and Villenoys; the rules of patriarchy create difficulties. Behn creates a world wherein Isabella's complicity within patriarchal rules slowly destroys her, and her story ends paradoxically in madness and violence as well as in morality and forgiveness.

Opening her narrative in a monastery, Behn accentuates the consequences of broken vows to lovers and to God, but also emphasizes that vow-breakers can avoid rash decisions about their fate if "nunneries and marriages were not to be entered into 'till the maid so destined were of a mature age to make her own choice."16 Isabella's father ostensibly takes her desires into account before she takes her vows, but at thirteen, she proves to be at a pre-sexualized age, as Catherine A. Craft has argued. ${ }^{17}$ Despite the fact that Isabella is courted by the handsome, rich, and nobly born gentleman, Villenoys, she refuses him for the cloistered life of a nun because she is not old enough to respond to romantic or sexual overtures; and her father and her aunt (the Abbess of the monastery which she will enter) encourage her decision to take vows, the former for convenience, the latter through the promise of her dowry. While condemning vowbreaking, the narrator emphasizes the role that proper patriarchal protectors should play in a woman's life, especially when she is too young understand or protect herself. After this premature decision, Isabella's first experience of sexual desire results in a disastrous struggle between sexual passion and the need to fulfill her obligations to her family and her vows.

From virgin ignorance, Isabella is soon restructured into a deceitful, ravenous desirer when, a few years later, at age sixteen, she falls passionately in love with Henault. Conflicting desires emerge as Isabella simultaneously tries to remain true to her religious vows and true to overpowering love. Behn describes the ways in which Isabella tries to banish her desire by trying

all that was possible in human strength to perform in the design of quitting a passion so injurious to her honor and virtue and found no means possible to accom- 
plish it. She had tried fasting long, praying fervently, rigid penances and pains, severe disciplines, all the mortifications almost to the destruction of life itself, to conquer the unruly flame; but still it burnt and raged but the more. ${ }^{18}$

Her desire tortures her, and her response is to torture it out of her body through mortifications of her flesh. The more she performs penance, the more her desire "burnt and raged." These unsuccessful efforts to "conquer" her desire for Henault-she prays, she fasts, she punishes herself-paradoxically lead her to conclude that God must be sanctioning her passion: she "submitted to her fate as a thing destined her by Heaven itself; and after all this opposition, she fancied it was resisting even Divine Providence to struggle any longer with her heart." 19 She identifies her desire for Henault with "Divine Providence," and finally makes the decision to escape the monastery in order to marry him.

Her new role as Henault's fond and pious wife solidifies the reader's sense of her passionate intensity and demonstrates the problematic consequences of her devotion to her husband; though the descriptions of her as a wife seem to describe her "perfection," they in fact demonstrate the ways in which patriarchal expectations of the "perfect" wife produce conflicting demands on women. Isabella and Henault are "examples of goodness and eminent for holy living and for perfect loving," and their "goodness" and "Holy living" seem constitutive of their relationship. ${ }^{20}$ Although the couple is pardoned by God, in the form of the bishop and her aunt, the Abbess, who provides Isabella with money from her monastery, they are not forgiven by Henault's father, who "refused to see him, or to receive any letters from him." ${ }^{21}$ Consequently, their married life is plagued by poverty and Henault is forced to join the army. When he tells the pregnant Isabella of his intentions, the idea "possessed her with so entire a grief that she miscarried," suggesting a devotion to her husband so intense that it destroys their child. ${ }^{22}$ This kind of emotional absolutism continues to define her character during his absence. When Villenoys, her first suitor, reports that he saw Henault die in battle and her grief devours her, she "hung her chamber in black and lived without the light of day." ${ }^{23}$

She is completely without financial support: her father has died, she fears returning to the monastery, her father-in-law will neither acknowledge nor support her. Villenoys, who still adores her, aggressively pursues her; after a protracted "courting" of about three years, she decides to remarry.

After she marries Villenoys, Isabella is again an unimpeachable wife, living a pious, quiet life, devoted to her new husband, and "in his arms, and alone, with him, she wanted nothing that could charm; so that she was esteemed the fairest and best of wives." ${ }^{24}$ With Isabella, it is invariably the absolute nature of her devotion that matters more than its object. Isabella's desires for Villenoys, Henault, and for the sanction of Providence and society become transgressive when they come into conflict with the rules of patriarchy that demand women have only one desire at a time (if at all). After Henault returns, having been a 
prisoner of war for seven years, Isabella's desire for her new husband and her sense of obligation to the first clash horrifically in the climactic murder scene: "Shame and confusion filled her soul, and she was not able to lift her eyes up to consider the face of him whose voice she knew so perfectly well." ${ }^{25}$ Isabella knows that she wants to remain married to Villenoys (her desire for him has replaced her feeling for Henault), but because she is trapped by the conflicting dictates of patriarchal ideology, she has no way of honorably staying in her second marriage. She has legal recourse, ${ }^{26}$ but a proceeding in court cannot remove the social stigma attached to bigamy, nor can it clarify her emotional confusion. Isabella finds that she must choose between her reputation (if Henault is acknowledged, she is adulterous in the eyes of society), her security (just out of prison, Henault has no way to support her), and her love for Villenoys. Unable to reconcile either her emotions or the competing imperatives of desire, security, and conjugal fidelity, she experiences a bewildering agony that mirrors the torment she experienced when she fell in love with Henault years earlier. She ponders her options as she prepares him for bed: returning to Henault as his wife or murdering him. Finally, "believing the murder the least evil, since she could never live with him, she fixed her heart on that." ${ }^{27}$ To her, murder is less evil than living with Henault, facing social condemnation as an adulteress, and losing Villenoys's love and support. In this sense, the murder is an attempt to simplify her desires, remain faithful to them, and retain her social identity.

However, after she smothers Henault, her latent but always absolute desire for him overwhelms her: "when she had done this dreadful deed, and saw the dead corpse of her once-loved lord lie smiling (as it were) upon her, she fell into a swoon with the horror of the deed." ${ }^{28}$ Her reawakened desire for Henault, the realization of the moral and social awfulness of her actions, and thoughts of what she will say to Villenoys swirl in her head and she begins to run mad. Her commitment to being the perfect wife-to absolute ideals of devotion-leads to an irresolvable conflict when she discovers that she loves two men who have equal claims to her through marriage and through her desire.

From the moment of Henault's return, despite her devoted and wifely behaviors, Isabella's desires are outside the sanctioned structures designed to protect her. Her inability to reconcile her conflicting desires manifests in the murder of both husbands. "Filled with thoughts all black and hellish" and "emboldened by one wickedness" (the murder of Henault), Isabella obfuscates the circumstances of both murders by sewing the sack containing Henault's corpse to Villenoys's collar. ${ }^{29}$ Once Villenoys reaches the river, "he threw himself with all his force backward, the better to swing the body into the river, whose weight ... pulled Villenoys after it, and both the living and the dead man [fell] into the river." ${ }^{\prime 30}$ When the circumstances of the murders are discovered and Isabella is accused, "she confessed the whole matter of fact, and, without any disorder delivered herself in the hands of justice as the murderess of two husbands (both beloved) in one night." ${ }^{\prime 11}$ The parenthetical phrase "both beloved" 
embodies the problem of her emotional absolutism: because Isabella wants both men and what they represent, her conflicting desires must be troped as excessive. Until the point of double murder, Isabella always has tried to do what is ideologically required: she agrees to become a nun according to her father's and aunt's wishes; she decides to run away with Henault after she convinces herself that God does not help her banish her desire for him; she waits years before she remarries; and she is an unexceptionable wife to both Henault and Villenoys. Because Isabella tries to reconcile her desires by falling back on socially prescribed roles, she fails miserably. The result of contradictions built into masculinist prescriptions for women is a psychological break and violence.

Yet her execution is not coded as a punishment, and she dies having solidified her reputation as a pious and virtuous woman. Behn emphasizes that this execution has become a scene of public mourning: "The whole world stood amazed at this; who knew her life a holy and charitable life, and how dearly and well she had lived with her husbands, and every one bewailed her misfortune." 32 Despite having committed the acts of a monster, Isabella on the scaffold looks like an angel, and "she set all hearts a flaming even in that mortifying minute of preparation for death." 33 This scene underscores the paradox of her death: she repeatedly tries to remain true to her desires and her proscribed roles, but she fails because there is no vocabulary, no place for multiple desires in her social world. Her wishes are irreconcilable in the context of a complex set of patriarchal injunctions that in their absolutism produce what seem to be irrevocable conflicts for women.

Isabella's intense and conflicted desires seemed to have puzzled adapters for the next seventy years because they pit readers' normative moral judgments against their possible sympathies for the heroine. Consequently, Behn's adapters essentialize Isabella's character by simplifying her desires in what amount to efforts to distract from, or deny the inherent contradictions within patriarchal ideology that Behn's narrative exposes. These adaptations of character fall into two groups. The first was that of the tragic, pious, virtuous victim, in the dramatic versions by Southerne and Garrick. The second was the changeable, lying, promiscuous murderer in the prose redactions by Barker, The Universal Spectator, and The Gentleman's Magazine. Despite the essentialized piousness or promiscuousness of character, all of the adaptations maintain Behn's social critique even as they try to deny or mitigate the intensity of the heroine's emotional state.

\section{TRAGEDY: THE PALIMPSEST OF VIRTUOUS DESIRE} AND THE EVENT OF SUICIDE

The revisions of Behn's History of the Nun as tragedy suggest that in order to figure Isabella as a victim, Southerne and Garrick must highlight her commitment to virtue, but they cannot erase Behn's core critique of patriarchal demands on 
women. Consequently, they re-create Isabella as a victim of irresponsible or evil men. In these stage adaptations she is tortured, not by competing desires, but by widowhood, new suitors, and vindictive in-laws. In making her wholeheartedly virtuous, Southerne and Garrick also make the patriarchs exceptionally evil. In fact, the men in the plays are either so crushing or so negligent that despite having two husbands, a father-in-law, and a brother-in-law, none can fully protect her from social and moral condemnation. Both adaptations therefore add the successful, "adaptive event" of suicide rather than double murder in their attempts to articulate a motive for Isabella's actions.

Southerne was a great admirer of Behn's who adapted two of her works, The History of the Nun and Oroonoko: or, The Royal Slave (1688), into popular plays. ${ }^{34}$ Much of his admiration can be seen in the subplot of this play, which takes on qualities of Behn's comedies: clever young women successfully dupe their guardians in order to marry their lovers. ${ }^{35}$ Southerne's Isabella is a late seventeenth-century tragic heroine: she is loving, devoted, suffering, and not prone to the kind of dissembling that define Behn's heroine. She becomes a heroine through her status as victim. ${ }^{36}$ Southerne's adaptation is the only version that identifies Behn's original narrative as its source, but the playwright claims ownership of his adaptation in the Epistle Dedicatory:

I took the Hint of the tragical part of this Play, from a novel of Mrs. Behn's, called The Fair Vow Breaker; You will forgive me for calling it a Hint, when you find I have little more than borrowed the Question[:] how far such a distress was to be carried, upon the misfortune of Woman's having innocently two husbands, at the same time. ${ }^{37}$

The Epistle Dedicatory also emphasizes the latter part of Southerne's title ("The Innocent Adultery") rather than the former ("The Fatal Marriage") and concentrates on the idea of innocent bigamy as a moral question, rather than exploring Isabella's intense and irreconcilable desires. In contrast to Behn's Isabella, who is both pious and aggressive, Southerne's heroine is pathetic and passive. Southerne's adaptation highlights the dutiful, devoted characteristics of Behn's Isabella, focusing on her virtuous behavior as a widow who chooses to live in poverty and near starvation with her son rather than remarry or give her son to her father-in-law.

Southerne's play opens years after Isabella's escape from the monastery, after her marriage to Biron (Henault's character), and after he presumably has died in war. Isabella has a child who embodies her "naturally" devastated feelings for her husband and her dedicated role as a mother. Villeroy has been courting her aggressively, and she finally accepts his marriage proposal to alleviate her extreme poverty. To emphasize these tragic virtues, she attributes her ill luck to the breaking of her nun's vows years earlier and blames her misfortune on her original desire for Biron: 
There, there began my woes.

O! had I never seen my Biron's face,

Had he not tempted me, I had not fall'n,

But still continu'd innocent; and free

Of a bad World, which only he had pow'r

To reconcile, and make me try agen. ${ }^{38}$

Biron's "temptation" begins her downfall and all of her misfortunes rest on that original sin; Southerne's imagery is suggestive of fatal or misplaced desire that recalls the familiar rhetoric of Eve's temptation and fall. Southerne specifically creates his Isabella as unchangeable, having (in her own mind) sinned by breaking her initial vows as a nun. She is entirely devoted to Biron, because she has "learnt" her lesson about rejecting vows; that lesson prevents her affections from shifting to another man.

Biron returns the day after her second marriage takes place, and his timely reappearance prevents Isabella's transferring affection from the first husband to the second. Southerne simplifies her response by effectively removing the desire for Villeroy that animated Behn's character. As an exemplary heroine, her affection for her first husband must remain steady. By having Biron return a day after her remarriage, Southerne ensures that his Isabella remains a mourning widow despite Villeroy's attractive qualities as a handsome, rich, and affectionate husband who saves her and her child from poverty and social ruin. To emphasize this point, the dramatist has Isabella and Villeroy make the marriage contract after he pays off her creditors. She resists the marriage, claiming she will never love him and that the moment is too intense and desperate for her to make proper decisions, claiming "I know / You would not wish to think I could be bought." ${ }^{39}$ She eventually relents, but love and desire are absent in her acceptance: "I give you all, / My hand; and would I had a heart to give; / But if it ever return again, 'tis wholly yours." 40

Thus when Biron returns, Isabella feels intense guilt about her second marriage; there is none of the inner struggle that Behn's heroine experiences. Southerne treats desire as unchanging and unconflicted in "good" women; once Isabella has loved and had a child, her desire is fixed to one man. His death, the cruelty of his family, and her abject poverty do not alter her desires, but confirm them. She is self-censuring; no one needs to articulate to her the problems of bigamy, misplaced love, or sex with a lawful husband she does not love because she repeatedly condemns herself for these faults. Her first thoughts at Biron's return are guilt over the second marriage, despair at her reputation, and pain at the joy that her in-laws will take in her demise; but her concluding thought is suicide rather than murder. She hopes

... to find a hospitable grave.

For that's the only bed, that's left me now. [Weeping] 
-What's to be done-for something must be done.

Two husbands! yet not one! by both enjoy'd,

And yet a Wife to neither! ${ }^{41}$

In Southerne's play, the heroine's madness has a clear impetus: the return of the man she loves and feels she has betrayed. Isabella's language emphasizes her passive suffering; she has two husbands and, instead of Behn's parenthetical "both beloved," she is "by both enjoy'd." Mortified that Biron sleeps in the very bed that was her second marriage bed, Isabella makes it clear that her guilt stems from the social stigma and personal horror of bigamy rather than an alteration of her affections. Southerne's Isabella's desires are not conflicted and consequently she remains the laudable, virtuous heroine.

The impact of Isabella's decision to murder Biron is deflated-murderous intent is conjured in a fit of madness and she stops before the fatal act. Rather than the cool reasoning of Behn's Isabella before the deed (who decides stabbing will be too messy and suffocation is the better option), Southerne's Isabella's murder attempt comes on the wave of over fifty lines of soliloquized madness. As she states, "Conflicting passions have at last unhing'd / The great Machine," and she wavers between adoring Biron, and not knowing who he is. ${ }^{42}$ When he calls for her, she exclaims, "A man's voice! In my bed! How came he there?" and draws a dagger. ${ }^{43}$ A Shakespearean knocking at the gate interrupts the scene; he wakes, she recognizes him, stays her hand, and flees. When we next see her, she attempts suicide because despite the fact that Villeroy and Biron "Divide my body to their equal claims; / My soul is only Biron's; that is free, / And thus I strike for him, and liberty"; death frees her from her own patriarchally imposed constraints. ${ }^{44}$ Despite the "equal claims" on her body, her soul and desires are unified in that they concentrate only in Biron; self-murder is her attempt to free her unified desire from her divided body. When madness retreats and realization sets in, she commits suicide; even though she represents an ideal virtue, she murders herself because she is not-and can never bevirtuous enough.

Tellingly, the second murder disappears from the play altogether. She must remain a tragic victim: the victim of vow-breaking, the victim of war, the victim of her in-laws, and the victim of Villeroy's aggressive and unrelenting courtship. And victims cannot murder, much less two husbands, and remain victims. Whereas Behn's heroine suffers from conflicted desires, Southerne's tragic heroine suffers from her own virtues and misfortunes. Behn's Isabella has strong passions and the ability to shift and change with her circumstances: she adjusts to life as a poor farmer's wife, she adjusts to the death of her husband, she adjusts to her remarriage-all her changes are important for her survival. Southerne's Isabella's supposedly "ideal" response to an impossible situation is not through adjustment, but suicide.

Garrick's reinterpretation of Southerne in 1757 as Isabella: or, The Fatal Mar- 
riage heightens the idea of Isabella as a tragic heroine even more. He removes Southerne's comic subplot because it is "indelicate [and] immoral," 45 and plays up Isabella's tragic fate. The "Advertisement" that appears before the 1758 printed version of the play suggests that Garrick's elimination of Southerne's subplot can be read as his heightening the tragic aspects of the protagonist, even more than Southerne, and augmenting her paralyzing passions. While fully acknowledging Southerne in the subtitle, The Fatal Marriage (Southerne's title), Garrick claims he added text because it was "absolutely necessary that Something should be supplied" to fill the vacuum left by the comic subplot of the play that he cut. He declares that he added so much to Isabella's role that Susannah Cibber, the famous tragedian, chose to "shorten [her] Speeches" rather than "spare [her] Powers" when she performed the role. ${ }^{46}$ Interestingly, a line-by-line comparison of the 1722 text of Southerne's play and Garrick's 1758 text reveals no actual additions to Isabella's speeches. ${ }^{47}$ Despite a clear provenance to Behn's originary text, despite the fact that he could have augmented the role with ideas that Southerne had eliminated from Behn, Garrick does not do what he claims; he does not expand Isabella's role at all. The absence of the subplot rather than additional lines clarifies the tragic aspects of her character. This strategy apparently was successful because the play was lauded for its intensity and its ability to evoke pathos, as The Theatrical Review noted: "The distress of the first three acts is exquisitely wrought... As to the distress of the Fifth, it is prodigious." ${ }^{48}$ Nevertheless, all of Isabella's speeches are directly taken from Southerne and only plot clarifications, rather than extended pathetic speeches, are added.

Southerne and Garrick reinterpret Isabella as a persecuted victim which, in turn, presents her as a moral spectacle. But neither Garrick's nor Southerne's overwriting can fully eliminate Behn's argument about the effects of patriarchal ideologies on women. Just as Behn implies that parents can be at fault for their children's behavior (as Isabella's father is in The History of the Nun, as Henault's stingy father is when he refuses financial support), Garrick and Southerne also emphasize how tragic women's lives are when irresponsible men make tyrannical decisions on women's behalf. In both versions, her father-in-law tries to pass over her son as heir; however, the logic of excluding the rightful heir fails. After his son and his daughter-in-law die, and his younger son is revealed as a traitor to him, the father-in-law must adopt his grandson; the proper heir is instated only once the patriarch destroys his eldest son's family. Those who abuse Isabella the most are also those who are most moved at her suicide and claim that she embodies "most injur'd Innocence" and that her death pulls "down this Judgment on us all." 49 The wrongs done to Isabella are ideologically rectified by the father-in-law's adoption of her son as his heir, but they destroy her in the process. Though Southerne and Garrick overwrite the discourse of competing desires which defines Behn's text, the palimpsest remains: a patriarchal society still fails to find space for women who fall socially, even if their virtue is inviolate. 


\section{MORAL FICTION: THE PALIMPSEST OF SEXUAL DESIRE AND THE EVENT OF MURDER}

The moral fiction adaptations of Behn's nun highlight her transgressive desire specifically by making capriciousness the core of her character. The fictional versions are in the didactic, controlling consciousness of a narrator; the protagonist stops being a character and is transformed instead into a type: "nun," "wife," or "widow" rather than "Isabella." These adaptations reinterpret her through her impulsive desires that exemplify women's "nature" as fickle and deceitful. This stereotype of women counters Southerne's and Garrick's interpretations of the "natural" tendency of ideal women to be faithful and virtuous. As contemporary rhetoric condemning women's infidelity underscored, once fallen, always fallen; redemption was not possible and social mores maintained it would be so. In the periodical versions (neither of which allude to the nun backstory), the protagonist's capaciousness is highlighted and linked to her "natural" (feminine) dishonesty. Boredom and the desire for something new are intrinsic to her sexual decisions and her inability to persist with either husband. Still, the palimpsest of Behn's critique of patriarchal ideologies for women who desire too much remains. These authors' representations of her fall as permanent condemn not only the fallen women, but also the inflexibility of marriage to accommodate any alteration of desires.

Barker's The Lining of the Patch-Work Screen: Design'd for the Further Entertainment of the Ladies (1726) is the third book of her Galesia trilogy. Barker's adaptation, "Philinda's Story out of the Book," is part of the Lining's "pane-work" narratives. ${ }^{50}$ Barker's critics roughly fall into two modes of analysis: first, the autobiographical nature of the trilogy and its subsequent questions of gender ${ }^{51}$ and genre ${ }^{52}$ and, second, her importance as a Jacobite and Catholic $\mathrm{c}^{53}$ to the thematic of her work.

The genre of The Lining of the Patch-Work Screen is complicated and elusive. Kathryn R. King calls them the "patchwork narratives"54 and Rivka Swenson pulls together her own patchwork of ideas to define the work's generic resistance. For Swenson they are "an array of pulse-points," "a layered event,"55 and "anti-novels ... constructed as histories in miniature, histories in bits and pieces" which follow an "anti-generic aesthetic." ${ }^{56}$ Swenson advocates that readers consider the aesthetic sequencing of the patchwork structure, that the entire piece of patchwork, all its various generic and thematic fabrics and textures, must be read as the larger square and only then can the aesthetic effects of the harmonies and sympathies be fully understood in a holistic context. ${ }^{57}$ Therefore, it is important to analyze what I will call the "Philinda Pane-work," a series of stories that contextualize Barker's adaptation of Behn's The History of the Nun.

The Philinda Pane-work begins with the arrival of Philinda and Lady Allgood at Galesia's tea table, and the telling of Philinda's story, from the mouth 
of Lady Allgood, that describes Philinda's recent marriage difficulties. Philinda has lent money to a gentleman friend without her husband's knowledge; the gentleman's jealous wife suspects them of adultery, and has them arrested and her husband sent away. Philinda has spent time in jail, despite her innocence, before finally admitting her role in the story. When the truth is revealed, all of the parties involved confess their actions, apologize for the trouble caused, and then re-couple happily, despite past distresses. The moral attached to this tale encourages husbands and wives to not have secrets from each other. While Lady Allgood relates the tale to Galesia, Philinda has retreated with Galesia's "old dirty rumpled Book" ${ }^{58}$ out of which she reads a version of The History of the Nun. (Galesia had read two tales from this book the night before- "The Adventures of an English Knight" and "The Cause of the Moors Over-running Spain" - tales which follow the misadventures of high-ranking men who fail to own up to their mistakes and make deals with the devil, respectively.) Philinda retells the tale, which is Barker's adaptation. In some ways, the adaptive event that Barker creates for her version of Behn's story is the "layered event" of Philinda's pane-work itself. The stories cannot fully be understood separate from each other.

It is tempting to reduce this version of the tale to a simplistic moral, in keeping with Barker's original reputation for morality, virtue, and piety as an oppositional and corrective reading to Behn's more libertine and proto-feminist ethos. Barker's revision at first appears to be based on a masculinist ideologyone false step, forever fallen-as the driving motivational explanation. Her adaptation reconfigures the protagonist's desires to an absolute rhetoric of inevitability and the irreversibility of sin. As a Catholic exile, Barker treats the nunnery and Catholicism as positive but failed influences, unable to contain this woman's illicit desires: "notwithstanding all the Care and Circumspection of those Places ... they [the Nun and her lover] found means to contract an Affection . . . [and] promis'd [each other] personal Enjoyment." ${ }^{59}$ Barker emphasizes the sexual connection between the Nun and her first husband; they marry for "personal Enjoyment," but her vow breaking is treated as an uncomplicated sin with no hint of a struggle over morals, desires, or duties. The Nun's first decision to "consent to the Temptation of the Flesh" marks her as irredeemable from this point forward. ${ }^{60}$ After clarifying this initial motivation, Barker is vague about any subsequent provocations. When the Nun remarries, the reader is told only "by what degrees or steps he climbed into her Affection, is yet unknown." ${ }^{61}$ The decision to murder is painted as her taking "a Wicked thought in her head," and although Barker adds that "no doubt her thoughts were greatly perplexed," she offers no narrative or authorial explanations; the heroine's confusion is the consequence of her initial vow-breaking. Divine retribution replaces the need for deeper motivation.

However, as King has pointed out, "Far from being exemplary or respectable, the life [of Barker] that has emerged over the last decade is one best evoked 
by terms like exile, estrangement, and political disaffection." ${ }^{62}$ Recent criticism almost demands that these patchworks be read within the context of Barker's Jacobitism and Catholicism, and King points out that bigamy recurs throughout the Galesia Trilogy — especially in the Lining — expressive of "divided loyalty" between king and country. ${ }^{63}$ With this in mind, the Nun can be understood better as an exile from king and country. If the Nun's bigamy is an allusion to Jacobite political (dis)loyalties, the Nun's vows to God are "king" and those to her husbands are "country," in which case both religiously and politically, the first broken vows are the most significant. When read in the pane-work frame, the tale takes on the specific quality of political and religious readings. The wife's inability to remain loyal to country (marriage vows) is an inevitable result of her inability to remain loyal to King (holy vows). Desire, then, becomes not the issue at stake, but a metaphor for punishment due to those who break vows. Thus the adaptive event takes on the aspect of divine retribution rather than a willful act of recovering self.

Barker highlights the moral failure of the protagonist by adding the adaptive event of the Wife's "accidental" part in the murder: "in her Fright, by mistake, took hold of the Gentleman's Coat, and so fastned that to the Sheet." ${ }^{64}$ Heaven or fate, rather than society or self, condemns Barker's heroine. She stitches herself into murderous action unknowingly, and the palimpsest of a critique of patriarchal ideology remains. The tale points out the problematic of the Nun's failed vows, but the political reading underscores the complications that ensue when there are failed patriarchs. In this case, the Stuarts' inability to reclaim the throne and the Nun's misplaced desire are both effects of that failure rather than personality flaws. ${ }^{65}$

The tendency to moralize over the now-unnamed protagonist continues into the adaptations published in The Universal Spectator (ca. 1728) and The Gentleman's Magazine (1731); the authors clarify her psychological motivation by emphasizing her lust and capaciousness. The Wife's lack of self-regulation is highlighted rather than the difficulties of her situation-these versions never mention "love" as a factor in the murders, only "change." The periodical versions may reinterpret the character as immoral as well as capricious, but the palimpsest of critique of patriarchal marriage remains. The Universal Spectator especially interweaves the monstrous wife with warnings about how marriage can be a burden to both sexes.

The frame of the Universal Spectator tale, "Sure, of all Ills, Domestic are the Worst!," puts the tale into conversation about the difficulty of dissolving marriages in the eighteenth century by invoking John Milton, whose "Spirit of Freedom ... exerted against the Bands of Matrimony, for confining us so inseparably to one Woman." 66 The text also takes care to list murderous wives from literature and history, including Hercules's wife Deianira (who tortured him with an "envenom'd" shirt), Queen Eadaburga (rumored to have poisoned her husband's enemies and eventually him), Mrs. Arden of Feversham (who got 
her lover to strangle her husband), and a "Mrs. Caldwell" (who poisoned her husband's oaten cake). ${ }^{67}$ While this litany clearly places the Wife in this murderous company, the author also frames her actions in the context of the problems inherent in the institution of marriage itself-it can lead to murderous wives and husbands alike. While the author declares that "you will ever find Adultery the most fruitful Root of these Matrimonial Murders," he quickly concedes, "Not but ... an inveterate Hatred and Antipathy arising from Ill-Usage, has often brought forth the same unhappy consequence." ${ }^{68}$ In calling attention to the "Ill-Usage" of women, the author shapes reasons for murder within marriage by rhetorics of masculine tyranny and abuse. In this way, "Sure, of all Ills" cannot fully rewrite the Wife's action as "simply" a monstrous murder because it offers a rationale for women's "Hatred and Antipathy" - the abuse that inheres in the tenets of patriarchal authority itself.

This tale eliminates the backstory of the wife as a runaway nun; it emphasizes the Wife's fickleness and disloyalty to her husband, while highlighting the effects of an aggressive suitor to a neglected wife. Her first husband "was probably of a more martial than uxorious Disposition," implying his likely disinterest in any woman he marries. ${ }^{69}$ The text augments the Wife's resentment at her husband's long neglect while he is at war: "She, who had but little Experience of his Affection, was yet much dejected at his Absence; for Women cannot bear any Thing which looks with the Face of a Slight, even from those [they] themselves disesteem. She strengthen'd her Apprehensions of being slighted, from the Silence of her Husband for several years after their Separation." ${ }^{\prime 70}$ In this text, the potential to sympathize with the protagonist cannot be completely overwritten. The narrator manages to imply an understandable motivation for her actions, even as it paints her as a disloyal wife. She feels "slighted," a sentiment which is made to seem petty when the narrator claims that she would feel the same distress were she ignored by a stranger she doesn't even like. Yet when her feeling of being "slighted" increases after a silence of "several years," the text also offers a motivation for the change in her affections for her absent and silent husband. Consequently, though the depiction of female desire is rewritten as fickle rather than tortured, the author cannot quite write out sympathetic aspects of the situation.

The adaptive event maintains this careful tension between criticism and sympathy. The second marriage is framed as manipulation on the part of Husband Two. On his sickbed, Husband One sends a ring to his wife with a friend to "convince her he [the first husband] was alive, and continued his Love to her." ${ }^{\text {71 }}$ But the friend "nourish'd a secret Passion for the Lady," and "presented the Ring as Part of her dead Husband's Last Will and Legacy."72 After mourning her lost husband, her fear of financial ruin and that such an opportunity won't come again prompts her to marry the dishonest friend. The narrator rewrites Behn's story to emphasize the manipulation of the second husbandqualities that his counterparts only have inklings of in other adaptations. This revision underlines the helplessness of women in questionable marriage states 
(especially widowhood) even as it underscores the problematic of marriage for both sexes, because right after it emphasizes the second husband's manipulation, it highlights her fickleness: "Soon after [the second marriage] her first Husband possessed her Imaginations more than ever, and she thought the latter did not use her so kindly; she Wished for another Dutch War, or that this [second husband] also would give her some Token of his Last Will" (i.e., she wishes Husband Two would also die). ${ }^{73}$ The author then hammers away at her capriciousness in such quick succession that the motivation for murder in this adaptation becomes clear. "The change was pleasing to her" when Husband One returns and "they again cohabited," but soon after "the Wind changed again" and she becomes gloomy. ${ }^{74}$ The author's language highlights the rhetoric of murder that occurs "merely for the Sake of Change and Variety," even as it demonstrates her Second Husband's manipulation.

The most significant addition in this version-one that elucidates her motivations as monstrous and selfish-are the author's descriptions of how the Wife manipulates Husband One into helping her murder Husband Two. When Husband One asks her why she's been so gloomy "she disclosed her deep concern to be, 'That he, her only Joy, should be in greater Danger at Home than in the Wars; having been credibly assured her Second had firmly resolved to murder him, the better to have Access to her again.'"75 She devises the murder plan and brings in the First Husband to assist her as they drug, then strangle Husband Two. ${ }^{76}$ The Wife's brazen seduction of Husband One to help her in the murder is not a particularly perplexing move in this text, though nearly unimaginable in any of the Isabellas. Rather than covering public shame or running mad, the Wife is interested in divesting herself of marriage partners altogether; the detail of purposefully stitching the live husband to the dead is retained, with the added detail that she helps to throw the corpse into the river. This adaptive addition clarifies the motivation, the situation, and the plot, as she "got rid of them both at once." 77 Her logic ultimately fails, of course. She is questioned, the bodies are found, she is "threaten'd with Torture, [which] terrify'd her into Confession," and while the reader is given no specifics of her penalty, "Justice inflicted on her the Punishment due to her Crimes." 78 She cannot throw off the patriarchal demands of marriage without deadly consequences to herself. Thus the critique of marriage remains, even while essentializing, simplifying, and blaming the protagonist; the palimpsest of masculinist manipulation and neglect is woven into the text.

The final adaptation, "Matrimonial Murders" in the Gentleman's Magazine, is a heavily compacted version. A mere 395 words, the adaptation races through plot, erasing nuances that other versions spend so much time developing. It even omits the macabre humor that makes "Sure, of all Ills" darkly amusing. The resulting compression continues an essentializing trend in emphasizing the wife's monstrosity and squeezes out most of the tension between criticism and sympathy that the Universal Spectator preserves. The text begins succinctly with adultery, moves quickly through the marriage, the First Husband's departure, and repeats 
the idea that "His Wife thought herself slighted, especially from the Silence of her Husband, which he continued several Years." ${ }^{79}$ As in the Universal Spectator, her capriciousness is highlighted by a succinct description of her dissatisfaction: "in a little Time, she dislik'd her second Husband." ${ }^{80}$ The adaptive event of her manipulating Husband One into murdering Husband Two remains, although it is compressed and linguistically efficient: "he must be dispatched or they could not be safe." ${ }^{11}$ Events unfold as they do in "Sure, of all Ills"; Husband Two is drugged and strangled, they carry the body through the late night streets, she holding the legs and "with a strong needle and thread, tack'd together the Coat Lappets of both her Husbands. When they came to the Brink of the Precipice, Now Wife, said he, are you ready? Now Husband, answer'd she-so down went the Dead, and the Living too." ${ }^{82}$ Even the compression of this adaptation from the already heavily truncated and reworked Universal Spectator version cannot pinch out all masculinist critique. In one half sentence, the author emphasizes that the Wife is neglected for many years. It is a mere textual moment. But it is difficult not to read this adaptation through its rich history, as an adaptation, through which we can still, just barely, recognize the palimpsest of Behn's originary text.

\section{CONCLUSION}

The fascination of Behn's originary text lies in its oddness, its drama, its ability to produce sympathy for and horror of Isabella even as it dismantles assumptions about patriarchal protections such as parents, nunneries, and marriages. This is also what seems to have frustrated her adapters. Behn is maddeningly unclear about Isabella's motivations, a dissatisfaction that adapters tried to make better sense of. But looking at this text through its adaptive history emphasizes that Behn's subject is the desire-driven psychological break that produces horrifying acts in otherwise typical people. The adaptations hold a key to unlocking those bits current readers find so frustratingly closed to explanation, even as they demonstrate Behn's achievement. By rereading the History of the Nun in the context of its adaptive history, the problems become a bit clearer: if unconventional women exist, or if they are prone to unconventional difficulties out of their control, they, nevertheless, are culpable. If adapters add comic subplots, if they emphasize suffering, if they cast aspersions on breaking vows, if they condemn characters to capricious selfishness, Behn's text is still in the background-and all those pieces help us to better navigate Isabella. They help us to clearly see that the root of Behn's critique of patriarchal social order cannot be easily erased. 
Appendix: Table of Adaptations of The History of the Nun

\begin{tabular}{|c|c|c|c|c|c|}
\hline Author & Title & Year & $\begin{array}{c}\text { Main } \\
\text { characters }\end{array}$ & Genre & $\begin{array}{l}\text { Adaptive } \\
\text { Event }\end{array}$ \\
\hline Aphra Behn & $\begin{array}{l}\text { The History of } \\
\text { the Nun; or, } \\
\text { The Fair Vow- } \\
\text { breaker }\end{array}$ & 1689 & $\begin{array}{l}\text { Isabella } \\
\text { Henault } \\
\text { Villenoys }\end{array}$ & $\begin{array}{l}\text { Amatory } \\
\text { fiction }\end{array}$ & $\begin{array}{l}\text { Isabella } \\
\text { smothers } \\
\text { Henault in a } \\
\text { fit of madness. } \\
\text { When sane, } \\
\text { she sews } \\
\text { Villenoys' } \\
\text { clothing to the } \\
\text { bag carrying } \\
\text { the dead body. }\end{array}$ \\
\hline $\begin{array}{l}\text { Thomas } \\
\text { Southerne }\end{array}$ & $\begin{array}{l}\text { The Fatal } \\
\text { Marriage: or, } \\
\text { the Innocent } \\
\text { Adultery }\end{array}$ & 1694 & $\begin{array}{l}\text { Isabella } \\
\text { Biron } \\
\text { Villeroy }\end{array}$ & $\begin{array}{l}\text { Restoration } \\
\text { tragedy } \\
\text { (with comic } \\
\text { subplot) }\end{array}$ & $\begin{array}{l}\text { Isabella } \\
\text { attempts to } \\
\text { stab Biron, } \\
\text { but commits } \\
\text { suicide } \\
\text { instead. } \\
\text { Biron dies of } \\
\text { wounds from } \\
\text { a sword fight. } \\
\text { Villeroy lives. }\end{array}$ \\
\hline Jane Barker & $\begin{array}{l}\text { "Philinda's } \\
\text { Story out of } \\
\text { the Book" in } \\
\text { The Lining } \\
\text { of the Patch- } \\
\text { Work Screen }\end{array}$ & 1726 & $\begin{array}{l}\text { The Nun } \\
\text { ("The } \\
\text { Wife") } \\
\text { First } \\
\text { Husband } \\
\text { Second } \\
\text { Husband }\end{array}$ & $\begin{array}{l}\text { "Patchwork } \\
\text { narratives" } \\
\text { didactic } \\
\text { tale } \\
\text { framed by } \\
\text { "romance" } \\
\text { tales }\end{array}$ & $\begin{array}{l}\text { The Wife } \\
\text { "murders" the } \\
\text { first husband } \\
\text { (specifics } \\
\text { not given). } \\
\text { The Wife } \\
\text { accidentally } \\
\text { sews the } \\
\text { living } \\
\text { husband's } \\
\text { clothing to the } \\
\text { dead. }\end{array}$ \\
\hline $\begin{array}{l}\text { unidentified: } \\
\text { likely, } \\
\text { Henry Baker } \\
\text { [Henry } \\
\text { Stonecastle, } \\
\text { pseud.] }\end{array}$ & $\begin{array}{l}\text { "Sure, of all } \\
\text { Ills, Domestic } \\
\text { are the } \\
\text { Worst!" in } \\
\text { The Universal } \\
\text { Spectator }\end{array}$ & ca. 1728 & $\begin{array}{l}\text { The Wife } \\
\text { First } \\
\text { Husband } \\
\text { Second } \\
\text { Husband }\end{array}$ & $\begin{array}{l}\text { Periodical } \\
\text { fable- } \\
\text { framed } \\
\text { with a } \\
\text { discussion } \\
\text { of Milton's } \\
\text { divorce } \\
\text { tracts }\end{array}$ & $\begin{array}{l}\text { The Wife } \\
\text { convinces } \\
\text { the first } \\
\text { husband to } \\
\text { help her drug } \\
\text { and strangle } \\
\text { the second. } \\
\text { She "tack'd } \\
\text { together the } \\
\text { Coat-Lappets } \\
\text { of both her } \\
\text { Husbands" } \\
\text { and assists in } \\
\text { throwing the } \\
\text { body into the } \\
\text { river. }\end{array}$ \\
\hline
\end{tabular}




\begin{tabular}{|c|c|c|c|c|c|}
\hline Author & Title & Year & $\begin{array}{c}\text { Main } \\
\text { characters }\end{array}$ & Genre & $\begin{array}{l}\text { Adaptive } \\
\text { Event }\end{array}$ \\
\hline $\begin{array}{l}\text { unidentified: } \\
\text { likely, } \\
\text { Edmund } \\
\text { Cave } \\
\text { [Sylvanus } \\
\text { Urban, } \\
\text { pseud.] }\end{array}$ & $\begin{array}{l}\text { "Matrimonial } \\
\text { Murders" } \\
\text { in The } \\
\text { Gentleman's } \\
\text { Magazine }\end{array}$ & 1731 & $\begin{array}{l}\text { The Wife } \\
\text { First } \\
\text { Husband } \\
\text { Second } \\
\text { Husband }\end{array}$ & $\begin{array}{l}\text { Periodical } \\
\text { fable }\end{array}$ & $\begin{array}{l}\text { The Wife } \\
\text { convinces } \\
\text { the first } \\
\text { husband to } \\
\text { help her drug } \\
\text { and strangle } \\
\text { the second. } \\
\text { She "tack'd } \\
\text { together the } \\
\text { Coat-Lappets } \\
\text { of both her } \\
\text { Husbands" } \\
\text { and assists in } \\
\text { throwing the } \\
\text { body into the } \\
\text { river. }\end{array}$ \\
\hline $\begin{array}{l}\text { David } \\
\text { Garrick }\end{array}$ & $\begin{array}{l}\text { Isabella: or, the } \\
\text { Fatal Marriage }\end{array}$ & 1757 & $\begin{array}{l}\text { Isabella } \\
\text { Biron } \\
\text { Villeroy }\end{array}$ & $\begin{array}{l}\text { Heroic } \\
\text { "She- } \\
\text { tragedy" }\end{array}$ & $\begin{array}{l}\text { Isabella } \\
\text { attempts to } \\
\text { stab Biron, } \\
\text { but commits } \\
\text { suicide. } \\
\text { Biron dies of } \\
\text { wounds from } \\
\text { a sword fight. } \\
\text { Villeroy lives. }\end{array}$ \\
\hline
\end{tabular}

\section{NOTES}

1. Aphra Behn, The History of the Nun: or, the Fair Vow-Breaker [1689], in Popular Fiction by Women: An Anthology, 1660-1730, ed. Paula R. Backscheider and John J. Richetti (Oxford, 1996), 1-42, 42.

2. See the Appendix for a chart organizing the different adaptations.

3. See esp. Jacqueline Pearson, "The History of The History of the Nun," in Rereading Aphra Behn: History, Theory and Criticism, ed. Heidi Hutner (Charlottesville, 1993), 234-52.

4. The copy of the Universal Spectator in the Eighteenth-Century Collections Online database is part of a collection published in 1747. The title page of the collection suggests an original publication date between 1728 and 1731 .

5. Authorial attribution is a complex subject for periodical articles in the 1700s. The fictitious author personae of the periodical pieces are Henry Stonecastle (likely Henry Baker) and Sylvanus Urban (likely Edmund Cave), respectively, though scholars agree that several authors probably worked under these pseudonyms. For Universal Spectator attributions, see Alvin Sullivan, British Literary Magazines: The Augustan Age and the Age of Johnson, 1698-1788 (Greenwood, 1983). For Gentleman's Magazine attributions, see Emily Lorraine de Montluzin, "Attributions of Authorship in the 'Gentleman's Magazine,' 1731-77: A Supplement to Kuist" (Studies in Bibliography 44 [1991]: 271-302).

6. Kirsten T. Saxton argues that the act of murder engages with contemporary sociopolitical notions of female morality and criminality (Narratives of Women and Murder in England 1680-1760: Deadly Plots [Burlington, 2003], 32-40). Critics have also focused on emotional/affective aspects of Isabella's character. Laura Linker reads Behn's Isabella as "Lady Sensibility," an important literary forerunner of later eighteenth-century heroines of sensibility (Dangerous Women, Libertine Epicures, and the Rise of Sensibility, 1670-1730 
[Burlington, 2011], 41-44 and 58-71). Elizabeth Matthews argues the narrative locates "humanity in wretchedness and power in resilience" ("'A Strange Sympathy': The Rhetoric of Emotion in The History of the Nun; or, The Fair Vow-Breaker," ABO: Interactive Journal for Women in the Arts 1640-1830 2, no.1 [2012]: 1-12, 2).

7. Pearson, 250-51n3.

8. Pearson, 250.

9. Pearson, 246.

10. See esp. Saxton, 38-39.

11. Much of this work has occurred in film criticism. See The Cambridge Companion to Literature on Screen, ed. Deborah Cartmell and Imelda Whelehan (Cambridge, 2007); Robert Mayer, "Introduction: Is there a Text in This Screening Room?," in Eighteenth-Century Fiction on Screen, ed. Robert Mayer (Cambridge, 2002), 1-15; Brian McFarlane, Novel into Film: An Introduction to the Theory of Adaptation (Oxford, 1996); and Whelehan, "Adaptations: The Contemporary Dilemmas," in Adaptations: From Text to Screen, from Screen to Text, ed. Cartmell (New York, 1999), 3-19. Useful text-to-text adaptation theory exists in Linda Hutcheon's A Theory of Adaptation (New York, 2006).

12. See McFarlane, "Reading Film and Literature," in The Cambridge Companion to Literature on Screen, 15-28, 15.

13. Whelehan, 16.

14. Hutcheon, 8 .

15. Regarding female desire and character in eighteenth-century fiction, see Nancy Armstrong, Desire and Domestic Fiction: A Political History of the Novel (New York, 1987); Ros Ballaster, Seductive Forms: Women's Amatory Fiction from 1684-1740 (Oxford, 1992); Katherine Binhammer, The Seduction Narrative in Britain, 1747-1800 (Cambridge, 2009); Toni Bowers, Force or Fraud: British Seduction Stories and the Problem of Resistance 1660-1760 (Oxford, 2011); and Patricia Meyer Spacks, Desire and Truth: Functions of Plot in EighteenthCentury English Novels (Chicago, 1990).

16. Behn, 5.

17. Catherine A. Craft, “Reworking Male Models: Aphra Behn's 'Fair Vow-Breaker,' Eliza Haywood's 'Fantomina,' and Charlotte Lennox's 'Female Quixote,'" Modern Language Review 86 (1991): 821-38, 825-26. Behn often sets her tales as "true histories" that she has heard or observed through interactions with nunneries and/or monasteries. Susan Goulding argues that, for Behn, "nuns offer the possibility of reading beyond individual texts and into the history of feminist thought" ("Aphra Behn's 'Stories of Nuns': Narrative Diversion and 'Sister Books,'”' Interdisciplinary Literary Studies 10, no. 1 (2008): 38-55, 39.

18. Behn, 24.

19. Behn, 24.

20. Behn, 28.

21. Behn, 28.

22. Behn, 29.

23. Behn, 31.

24. Behn, 33.

25. Behn, 35.

26. Eighteenth-century law had provisions for accidental polygamy that gave power to the woman in the event that a presumed-dead husband reappeared. According to Lawrence Stone, "a man or woman whose spouse had left home and had not been heard of for a period of seven years was also free to remarry, on the assumption that the missing spouse was dead. If he or she returned, however, either the first marriage took priority over the second or the woman was permitted to choose which husband she preferred" (The Family, Sex and Marriage in England, 1500-1800 [New York, 1979], 37-38).

27. Behn, 37.

28. Behn, 37.

29. Behn, 39. This act of sewing, which is important to feminist criticism of this text, is 
not present in all of the adaptations, and so has not been considered as part of the adaptive events. For the importance of stitching in this text, see Pearson, 247, and Saxton, 38.

30. Behn, 39.

31. Behn, 42.

32. Behn, 39.

33. Behn, 39.

34. They also worked with the same actors: Elizabeth Barry played Hellena in Behn's The Rover and Isabella in Thomas Southerne's The Fatal Marriage, and Thomas Betterton played both Wilmore and Villeroy (Southerne's renamed Villenoys).

35. Victoria, the heroine of Southerne's comic subplot, dresses in male clothes to test and then run away with her lover; her father, an old, remarried, rich man, miserly with his daughter's dowry, believes his wife will cuckold him. Southerne's is the only version in which this subplot exists. See Pearson, 236-40.

36. See Jean I. Marsden, Fatal Desire: Women, Sexuality and the English Stage, 1660-1720 (Ithaca, 2006).

37. Thomas Southerne, "Epistle Dedicatory," The Fatal Marriage; or, The Innocent Adultery (London, 1694), n.p.

38. Southerne, 17.

39. Southerne, 27.

40. Southerne, 29.

41. Southerne, 61.

42. Southerne, 65.

43. Southerne, 66 .

44. Southerne, 68.

45. David Garrick, "Preface," Isabella: or, The Fatal Marriage. A Play Alter'd from Southerne (Dublin, 1758), n.p.

46. Garrick, "Advertisement," Isabella: or, The Fatal Marriage. A Play Alter'd from Southerne (Dublin, 1758), n.p.

47. Garrick's changes mostly deal with plot continuations that were lost in the removal of the comic subplot; he also adds lines to the role of Isabella's son (see Pearson, 237). One significant change to root out Restoration-style "indecency" occurs. In Southerne's version, a song sung before the wedding highlights the expected sexual pleasures of the consummation, emphasizing how the bride's "blushes become her, her passion is eas'd" (40). In Garrick's version, the wedding song is changed to encourage the newlyweds to "Take the Blessing Gods intend ye; / Grateful meet the proffer'd Joy: / Truth and Honour shall attend ye, / Charms that ne'er can change or cloy" (29).

48. According to G. W. Stone, the tragedy played eleven times during the 1757-58 season (The London Stage: 1660-1800. Part IV: 1747-1776, ed. G.W. Stone [Carbondale, 1962], 630).

49. Garrick, 59.

50. Jane Barker, "Philinda's Story out of the Book" [1726], in The Galesia Trilogy, ed. Carol Shiner Wilson (New York, 1997), 214-17. Critics tend to emphasize the patchwork aspect of the last two books of the trilogy; however, for this particular book Barker states, "But these Pieces being much larger than the others, I think we must call it Pane-work" (177).

51. See Spacks, Imagining a Self: Autobiography and the Novel in Eighteenth-Century England (Cambridge, 1976); and Jane Spencer, "Creating the Woman Writer: The Autobiographical Works of Jane Barker," Tulsa Studies in Women's Literature 2, no. 2 (1983): 165-81.

52. See Cheryl L. Nixon, “'Stop a Moment at this Preface': The Gendered Paratexts of Fielding, Barker, and Haywood," Journal of Narrative Theory 32, no. 2 (2002): 123-53; and Rivka Swenson, "Representing Modernity in Jane Barker's Galesia Trilogy: Jacobite Allegory and the Patch-Work Aesthetic," Studies in Eighteenth Century Culture 34 (2005): 55-80.

53. See Carol Barash, English Women's Poetry, 1649-1714: Politics, Community and 
Linguistic Authority (Oxford, 1996); Bowers, "Jacobite Difference in the Poetry of Jane Barker," ELH 64, no.4 (2007): 857-69; Kathryn R. King and Jeslyn Medoff, "Jane Barker and Her Life (1652-1732): The Documentary Record," Eighteenth-Century Life 21, no. 3 (1997): 16-38; King, Jane Barker, Exile: A Literary Career 1675-1725 (Oxford, 2000); Wilson, "Introduction," in The Galesia Trilogy and Selected Manuscript Poems of Jane Baker (Oxford, 1997), xv-xliv; and Leigh A. Eicke, "Jane Barker's Jacobite Writings," in Women's Writing and the Circulation of Ideas: Manuscript Publication in England, 1550-1800, ed. George L. Justice and Nathan Tinker (Cambridge, 2002), 137-57.

54. King, Exile, 159.

55. Swenson, 55.

56. Swenson, 56.

57. Swenson, 57-61.

58. Barker, 202. I have been unable to trace what exactly this book might be, if it is not a fictional construct.

59. Barker, 214.

60. Barker, 214.

61. Barker, 215.

62. King, Exile, 10.

63. King, Exile, 167.

64. Barker, 217.

65. While the failure of the Stuarts to retain the throne wasn't certain at the time of the writing of Lining, it was becoming inevitable, though critics argue the specifics of this. See for instance, King, Jane Barker, Exile (chap. 4, "A Jacobite Novelist," 147-79); Swenson, 61-65.

66. Henry Baker [Henry Stonecastle, pseud.], "Sure, of all Ills, Domestic are the Worst!" [ca. 1728], The Universal Spectator, 4 vols. (London, 1747), 3:58-62, 60.

67. Baker, 60.

68. Baker, 60 .

69. Baker, 60 .

70. Baker, 60 .

71. Baker, 60-61.

72. Baker, 61.

73. Baker, 61.

74. Baker, 61.

75. Baker, 61.

76. In this version, the second husband is murdered initially rather than the first husband. All previous iterations have the first husband (Henault/Biron) murdered first.

77. Baker, 62.

78. Baker, 62.

79. Edmund Cave [Sylvanus Urban, pseud.], “Matrimonial Murders,” The Gentleman's Magazine 1 (1731): 463-64.

80. Cave, 464.

81. Cave, 464.

82. Cave, 464. 
Copyright of Eighteenth Century: Theory \& Interpretation (University of Pennsylvania Press) is the property of University of Pennsylvania Press and its content may not be copied or emailed to multiple sites or posted to a listserv without the copyright holder's express written permission. However, users may print, download, or email articles for individual use. 